\title{
18. THE PHYSICAL NATURE OF YOUNG UPPER OCEANIC CRUST ON THE MID-ATLANTIC RIDGE, DEEP SEA DRILLING PROJECT HOLE 395A ${ }^{1}$
}

\author{
R. D. Hyndman, Pacific Geoscience Centre, Earth Physics Branch, Department of Energy, Mines and Resources, \\ Sidney, British Columbia \\ and \\ M. H. Salisbury, Deep Sea Drilling Project, Scripps Institution of Oceanography²
}

\begin{abstract}
The physical nature of the upper oceanic crust at DSDP Site 395 on the Mid-Atlantic Ridge was studied on Leg 78B using laboratory measurements on core and water samples; a suite of conventional downhole logs; and a series of special logs, downhole measurements and experiments, including a downhole magnetic log, temperature logs, a televiewer $\log$, in situ permeability and aquifer pressure measurements with a downhole packer; and a seismic refraction experiment involving a downhole seismometer and ocean-bottom seismographs. Langseth et al. (this volume) provide a synthesis of the implications of the resulting data for the hydrogeology of the ocean crust at the site. This chapter provides a synthesis of the physical properties of the upper crust at the site over a range of physical scales. A marked change in porosity, electrical resistivity, compressional- and shear-wave velocity, thermal properties, and permeability at a subbasement depth of $400 \mathrm{~m}$ suggests that Hole 395A penetrated the Layer $2 \mathrm{~B} / 2 \mathrm{C}$ transition. An improved definition and interpretation of the crustal lithology penetrated by the hole, as determined by the downhole measurements, is also presented.
\end{abstract}

\section{INTRODUCTION}

In March 1981, Hole 395A on the Mid-Atlantic Ridge was re-entered to a depth of $609 \mathrm{~m}$ (497 m into the ocean crust) for the specific purpose of conducting a series of downhole physical-state and physical-properties measurements. A second objective was to test the deployment of a long-term recording seismometer in the seafloor and to employ it in a two-ship seismic refraction experiment designed to study the crust around the site. The measurements and experiments included a suite of conventional downhole logs run by Gearhart Industries, a downhole magnetometer $\log$, borehole temperature measurements, a televiewer log, a study of borehole water chemistry, in situ permeability and aquifer pressure using a downhole packer, and a seismic refraction experiment employing borehole seismometer recording. In addition, new laboratory measurements of the physical properties of core samples were made to supplement data collected by the original Leg 45 scientific team and to complement the downhole measurements. Each of the measurements is discussed in more detail in the individual chapters of this volume. In a companion chapter, Langseth et al. (this volume) provide a synthesis of the implications of the temperature and packer data for the hydrogeology of the ocean crust at the site. This chapter provides a synthesis of the physical nature of the crust at the site. An improved definition and interpretation of the crustal lithology penetrated by the hole, as provided by the downhole measurements, is also presented.

\footnotetext{
${ }^{1}$ Hyndman, R. D., Salisbury, M. H., et al., Init. Repts. DSDP, Vol. 78B: Washington (U.S., Govt. Printing Office).

Addresses: (Hyndman) Pacific Geoscience Centre, Earth Physics Branch, Dept. of Energy, Mines and Resources, P.O. Box 6000, Sidney, B.C., V8L 4B2, Canada; (Salisbury) Deep Sea Drilling Project A-031, Scripps Institution of Oceanography, La Jolla, CA 92093.
}

Our understanding of the physical properties and physical state of the ocean crust has been significantly advanced by data related to a series of Deep Sea Drilling Project boreholes that have penetrated the crust to depths of over $500 \mathrm{~m}$. Estimation of the bulk physical properties and state of the upper crust have, however, been seriously impaired by poor core recovery, commonly only $20 \%$, and by the difficulty of simulating in situ conditions in the laboratory. The few boreholes in which in si$t u$ downhole logging and other downhole measurements were undertaken are therefore of critical importance. To date, logs have been run more than $100 \mathrm{~m}$ into normal ocean crust at only four sites, including the present hole, 395A. Hole 396B on the Mid-Atlantic Ridge was logged $200 \mathrm{~m}$ into 10-Ma-old crust (Kirkpatrick, 1979a, b). Hole 417D in the western Atlantic was logged $100 \mathrm{~m}$ into 106-Ma-old Cretaceous crust (Salisbury, Donnelly, and Francheteau, 1980; Salisbury, Stephen, et al., 1980). Hole 504B in the Costa Rica rift area was logged $1000 \mathrm{~m}$ into 6-Ma-old crust (Anderson, Honnorez, et al., 1982).

In interpreting the data from the various sites, it is important to recognize the different crustal environments. Holes 395A and 396B are in young fractured crust from a slowly spreading ridge with little sediment cover. The upper crust at these sites has been kept cool by hydrothermal circulation. Hole 504B penetrated young smooth crust from a moderately fast spreading ridge, with a widespread impermeable sediment cover. There has been little cooling by hydrothermal circulation at this site, and the upper crustal temperatures are high. Hole 417D was drilled into old ocean crust with an extensive sediment cover. The crust has been significantly consolidated and altered. Thus, the upper crustal properties discussed herein can be taken as typical only of young ocean crust on a slowly spreading ridge with little sediment cover. 
The physical properties considered are compressional$\left(V_{p}\right)$ and shear- $\left(V_{s}\right)$ wave velocity, electrical resistivity, thermal conductivity and diffusivity, magnetization and susceptibility, density, porosity, and permeability. The effect of different in situ conditions on these properties has also been considered, particularly in the case of the sample measurements. Of particular importance in this study is the comparison of physical properties estimates from different scales of measurement: core samples represent a scale of investigation of a few centimeters; downhole logs represent a scale of tens of centimeters to meters; and refraction experiments and surface ship data represent hundreds of meters to kilometers. Other studies, for example, have suggested that ocean crustal porosity results in part from vesicular and grain-boundary porosity (as seen in core samples) and in part from larger fractures and rubble (as seen in logs and larger-scale measurements). It appears that most of the crust's permeability is associated with the larger-scale porosity not seen in core samples.

\section{SUMMARY OF LABORATORY SAMPLE PHYSICAL PROPERTIES}

Laboratory measurements of the physical properties of core samples from Hole 395A have been reported by Melson, Rabinowitz, et al. (1979b), Schreiber and Rabinowitz (1979) and Hyndman et al. (this volume). They include density, porosity, compressional- and shearwave velocity, thermal conductivity and diffusivity, electrical resistivity, magnetization, and susceptibility. It has been emphasized that the data may not be representative of the section drilled, even when in situ temperature and pressure conditions are simulated, because of the poor and biased core recovery. Thus, the relations among the parameters, particularly the relations with respect to porosity or density are very important. These relations, applied to downhole logs and marine geophysical data, permit estimates to be made of most of the bulk in situ physical properties of the upper ocean crust.

The mean physical properties of laboratory samples from the Hole 395A basalts are summarized in the following list; relations among the parameters are discussed in subsequent text.

$\begin{array}{ll}\text { Porosity: } & 5 \% \\ \text { Density: } & 2.84 \mathrm{~g} / \mathrm{cm}^{3} \\ \text { Electrical resistivity: } & 500 \mathrm{ohm}-\mathrm{m} \\ \text { Velocity } V_{p}: & 6.00 \mathrm{~km} / \mathrm{s} \\ \quad V_{s}: & 3.18 \mathrm{~km} / \mathrm{s} \\ \text { Poisson's ratio: } & 0.30 \\ \text { Thermal conductivity: } & 1.77 \mathrm{Wm}^{-1 \circ} \mathrm{K}^{-1} \\ \text { Thermal diffusivity: } & 0.68 \mathrm{~mm}^{2} \mathrm{~s}^{-1} \\ \text { Susceptibility: } & 2.6 \times 10^{-2} \mathrm{SI} \text { units } \\ \text { Magnetization: } & 3.78 \times 10^{-3} \mathrm{emu} / \mathrm{cm}^{3} \\ \text { Permeability: } & 10^{0}-10^{-3} \mu \text { darcies } \\ & \text { (fresh and altered } \\ & \text { basalts from DSDP } \\ & \text { Hole } 418 \mathrm{~A} ; 1 \text { darcy } \approx 10^{-12} \mathrm{~m}^{2} \\ & \text { [Johnson, 1980].) }\end{array}$

\section{DOWNHOLE LOGS}

In common with all previous efforts to obtain standard downhole logs in crustal boreholes, the quality of the data for Hole 395A was sometimes poor because of hole enlargement, because of the severe special constraint on the Glomar Challenger that the tools must pass down a drill pipe of small inside diameter and operate in a large-diameter hole, and because of the lack of tool calibration for ocean crustal rocks (see Mathews et al., this volume). The data are adequate, however, to provide some very important limits on the lithology and physical properties of the crust. The deep-investigating laterolog gave excellent quantitative electrical resistivity data, as did the caliper and gamma-ray logs, although the latter gave limited information because of the low potassium concentrations in the basalts. The density data are of only fair quality owing to the effect of hole enlargement and washout. Good velocity data were obtained only for the lower portion of the hole. The neutron porosity log was of poor quality because of the large and variable hole diameter. Temperature logs of good quality were obtained.

Of the special logs, the downhole magnetometer and susceptibility tool gave excellent data, although the horizontal field could not be measured, because the tool requires an inclined hole to maintain horizontal orientation. The televiewer data were seriously degraded by instrument mechanical problems and by ship's heave.

\section{Log Definition of Lithology}

The average core recovery in most crustal holes is very low; in Hole $395 \mathrm{~A}$ it was only $19 \%$, and in some zones it was even lower. This small and biased recovery gives added importance to the definition of the lithology by downhole logs. The lithology penetrated by Hole 395A is strikingly well defined by the logs, confirming in general the units described by the Leg 45 scientific party using core, chemical, and petrological data (Melson, Rabinowitz, et al., 1979a), and precisely defining the boundaries and demonstrating important trends within individual units. All of the Units $\mathbf{A}_{2}$ through $\mathrm{A}_{4}$ identified in the core, as well as a new unit boundary within Unit $A_{3}$, are particularly well defined by the downhole resistivity $\log$ (Fig. 1).

\section{Magma Cycles}

Resistivity decreases steadily from the bottom to the top of each chemical unit (usually consisting of numerous flows), by at least a factor of 2 and by nearly a factor of 10 in the thicker units. This trend is taken to reflect primarily an increase in porosity toward the top of each unit, and it can also be seen to some degree in all the other logs that are porosity-sensitive. Some of the logs are seriously affected by hole diameter, however, and may in part reflect the variations in diameter identified by the caliper. The caliper log itself, though, shows the trend within each unit; the high-porosity rubble and fractured material near the top of each unit is subject to washout and hole enlargement. The hole is near to gauge (i.e., bit size) at the bottom of the units, and is enlarged an average of some $20 \%$ near the tops. We note that there may be, upward through each unit, an increase in alteration associated with the increase in porosity and thus in available water. 


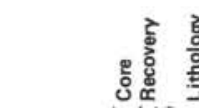

䱏

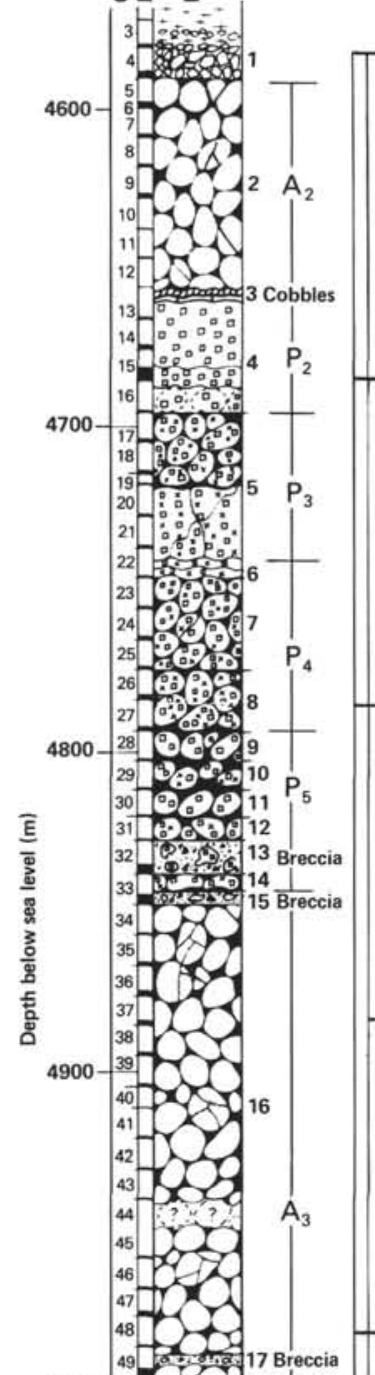

Caliper

Density

Resistivity

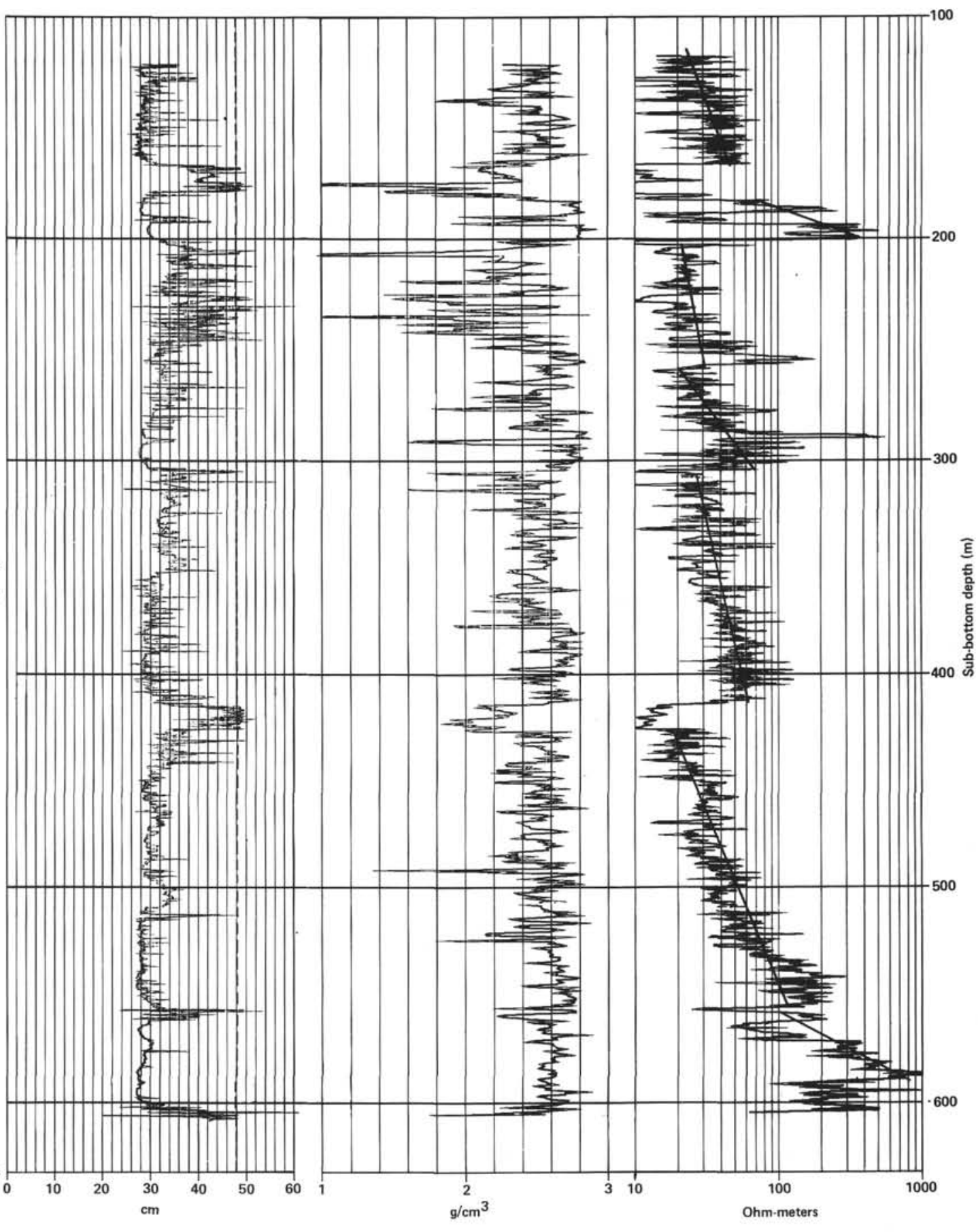

5149 ${ }_{67}^{67}$ ह त्र

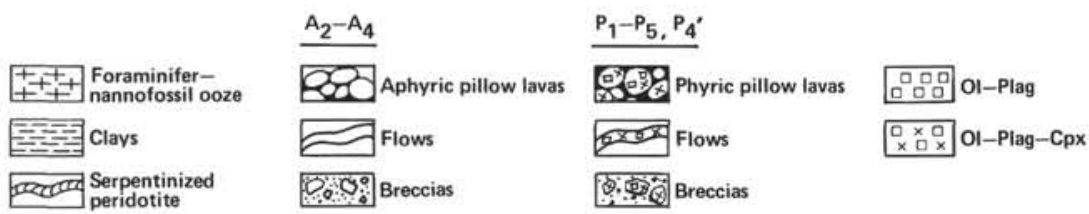

Figure 1. Caliper, density, and borehole-corrected resistivity logs obtained on Leg 78B in Hole 395A. Lithology from Melson, Rabinowitz, et al. (1979b). Dashed line on caliper log indicates maximum extension of caliper. Heavy lines superimposed on resistivity log show units inferred from resistivity trends. 
One may explain both the chemical differences among the main lithologic units and the distinctive trend in log response from bottom to top within each unit by the hypothesis that each unit represents an eruptive cycle from a particular source, and that each unit is probably from a different magma chamber. Each cycle appears to commence at the bottom with relatively massive flows and pillows, and gradually trends to more flow breccia and rubble toward the top of the unit, probably because the lava became progressively more viscous. Since there are no systematic chemical or petrologic fractionation trends within the units (Melson, Rabinowitz, et al., 1979a; Bougault et al., 1979), these changes probably reflect a gradual decrease in temperature in the source magma chamber and thus an increase in the viscosity. Only a small change in magma temperature is required to produce this effect (see discussion in Davis, 1982). Alternatively, the increasing viscosity could reflect a decreasing magma water content, although a steady change in chemistry should then be expected.

\section{Plutonic Units}

The pair of massive units $\left(\mathrm{P}_{2}\right)$ between about 180 and $200 \mathrm{~m}$ sub-bottom is another lithologic feature clearly defined on all the logs, including the televiewer log. Each unit is about $7 \mathrm{~m}$ thick, and they are separated by a thin high-porosity zone. They are overlain in the hole by a section of rubble identified in the core as plutonic rocks consisting of gabbro and serpentinized peridotite, only a small amount of which was recovered from the main Hole 395A. However, two plutonic units were identified in the core from the adjacent pilot Hole 395 . Even in the latter hole their depth relationship was not well known, because of the poor core recovery. Samples from the upper unit are primarily serpentinized harzburgite, and those from the lower unit are serpentinized lherzolite with associated gabbro. It is interesting that the downhole magnetometer logs indicate the presence of two plutonic units in Hole 395A as well, one above the massive unit pair and one below. Both show high susceptibility, but only the lower unit indicates high magnetization. Such plutonic units have been recovered in other Mid-Atlantic Ridge boreholes (e.g., Aumento, Melson, et al., 1977), but it is still unclear how material thought to be typical of the lower crust is emplaced in the upper crust. Since the regional topography, which is in part fault-block-induced, locally exceeds the thickness of Layer 2, it is possible that the plutonics at Site 395 represent talus from nearby scarps.

\section{High-Porosity Rubble or Breccia Zones}

The logs, particularly the caliper and televiewer logs (Hickman et al., this volume), readily define zones of high porosity, inferred to be high-permeability rubble and breccia. Most of these zones are near unit boundaries and probably represent the last phase of an eruptive cycle. They include the plutonic rubble above Unit $\mathrm{P}_{2}$; a broad irregular zone containing plutonics below unit $\mathrm{P}_{2}$; a pronounced 10 -m-thick zone near $420 \mathrm{~m}$ sub-bottom; a narrow zone near $560 \mathrm{~m}$ sub-bottom; and at the bottom of the open hole at $609 \mathrm{~m}$ sub-bottom.

\section{Estimates of Large-Scale Physical Properties}

In this section we obtain estimates of the large-scale physical properties of the crustal section penetrated by Hole 395A: its density, porosity, electrical resistivity, seismic velocity, Poisson's ratio, thermal conductivity, thermal diffusivity, permeability, and magnetic susceptibility. The data come from core sample measurements, downhole logs and measurements, and the seismic experiment. Empirical and theoretical relations among the parameters are used to obtain unmeasured or poorly determined properties from the better determined ones.

Porosity is the most important determining factor for most crustal physical properties, since the properties of the matrix in the basalt section vary only very little and the pore fluid is usually close in composition to seawater. The correlation with bulk porosity is very good for most properties, although pore structure is important for some. A smaller variation in the physical properties results from matrix differences, particularly in the amount of alteration. Since porosity is at least qualitatively related to permeability, it is also an important parameter for the interpretation of temperature and hydrothermal circulation data.

All the parameters except density depend to some degree on the pore structure as well as the porosity; the effect is pronounced for permeability, moderate for electrical resistivity and velocity, and fairly small for the thermal and magnetic properties. Thus, some estimates must be made of the nature of the porosity structure. The extremes are well-connected (large aspect ratio) cracks and fissures and poorly connected (small aspect ratio) vesicular porosity.

Fortunately, in this study, the electrical resistivity, one of the parameters most sensitive to porosity, is also the property for which the highest quality log measurements were obtained in Hole 395A (Mathews et al., this volume). The resistivity can thus be used to estimate other parameters as a function of depth in the hole or to interpolate between sections of reliable data obtained with the other logs. The method does suffer, however, from systematic variations in pore structure. For low-porosity sections, the vesicular or poorly connected porosity will dominate, whereas for high-porosity sections (cracks and rubble), well-connected porosity will dominate.

Formation physical properties are summarized in Table 1.

Table 1. Summary of Hole 395A formation physical properties.

\begin{tabular}{lcc}
\hline \multicolumn{1}{c}{ Property } & $\begin{array}{c}\text { Average } \\
\text { to } 400 \mathrm{~m} \\
\text { into crust }\end{array}$ & $\begin{array}{c}\text { Bottom } \\
100 \mathrm{~m}\end{array}$ \\
\hline Porosity (\%) & 8.7 & 4.7 \\
Density $\left(\mathrm{g} \mathrm{cm}^{-3}\right.$ ) & 2.78 & 2.86 \\
Electrical resistivity (ohm-m) & 40 & 130 \\
Velocity $V_{p}\left(\mathrm{~km} \mathrm{~s}^{-1}\right)$ & 5.66 & 6.00 \\
Velocity $V_{s}\left(\mathrm{~km} \mathrm{~s}^{-1}\right)$ & 2.90 & 3.15 \\
Poisson's ratio & 0.28 & 0.26 \\
Thermal conductivity $\left(\mathrm{W}_{\mathrm{2}} \mathrm{m}^{-1}{ }^{\circ} \mathrm{K}^{-1}\right)$ & 1.71 & 1.77 \\
Thermal diffusivity (mm $\mathrm{s}^{-1}$ ) & 0.64 & 0.68 \\
Susceptibility (SI units) & $1.4 \times 10^{-2}$ & $1.2 \times 10^{-2}$ \\
Permeability ( $\mu$ darcies) & 400 & 5 \\
\hline
\end{tabular}




\section{Formation Resistivity}

The resistivity as determined by the downhole guard resistivity log (deep laterolog) appears to be well determined (see Fig. 1 and Mathews et al., this volume). However, even this tool, which is relatively insensitive to hole enlargement, will have been affected, and the resistivity will be too low in the major washout zones where the caliper was fully extended. The mean laboratory sample resistivity of about $500 \mathrm{ohm}$-m agrees well with the maximum resistivity peaks in the log of 400 to $1000 \mathrm{ohm}-\mathrm{m}$, so the tool calibration and borehole correction are taken to be adequate. For most of the hole, the resistivity log ranges from about 20 to $80 \mathrm{ohm}-\mathrm{m}$. For the bottom $100 \mathrm{~m}$ of the hole, however, there is a rapid rise in resistivity that is particularly interesting. This is the depth range over which there is a rapid increase in formation temperature, as estimated from downhole measurements and from oxygen isotope data, and an increase in alteration. The increasing resistivity could simply reflect decreasing porosity, but this trend is not evident in the density log. The sample data unfortunately are inadequate to clearly resolve the effect, but there is a general increase in sample resistivity, velocity, and thermal conductivity in this depth range. The increasing resistivity may be the result of alteration decreasing the interconnection between pore spaces, which increases the resistivity for a particular porosity. Thus, the maximum depth of cooling by hydrothermal circulation and the associated depth below which higher-temperature alteration becomes important in the crust may be marked by a general rapid increase in resistivity. If this is so, seafloor electrical methods may offer the best way to determine the depth of hydrothermal circulation in different areas of the seafloor. A similar rapid increase in resistivity and decrease in porosity and associated properties has been observed about $600 \mathrm{~m}$ sub-basement in Hole 504B on the Costa Rica Rift (Anderson, Honnerez, et al., 1982). The amount of alteration also increased rapidly below that depth.

\section{Formation Porosity from Resistivity Log}

The relation between porosity and resistivity for oceanic basalts is a well-defined function. Because the resistivity $\log$ is thought to be the highest quality $\log$ for Hole $395 \mathrm{~A}$, it is used to estimate the porosity and then several other properties of the formation. For this reason, the electric resistivity-porosity relation is discussed in some detail here.

The electrical resistivity of a rock saturated with a conducting fluid, for which the matrix has a high resistivity, is found to follow closely the Archie's Law (1942) relation

$$
\frac{R_{0}}{R_{w}}=a \phi^{-m}
$$

where $R_{0}$ is the bulk resistivity, $R_{w}$ is the fluid resistivity ( $R_{0} / R_{w}$ is called the formation factor), $\phi$ is the porosity, and $a$ and $m$ are constants which vary with the pore structure (e.g., Brace et al., 1965). The resistivity of the matrix is unimportant unless it is very conductive (e.g., less than $1000 \mathrm{ohm}-\mathrm{m}$ ), as may be the case for highly altered hydrated rocks, or if the porosity is very poorly connected (i.e., vesicular). Drury and Hyndman (1979) measured an extensive suite of oceanic crustal rock samples that had been dried, and found all to be highly resistive. The resistivity of seawater, which is assumed to fill the pore spaces, is strongly temperature-dependent and slightly pressure-dependent, but for Hole $395 \mathrm{~A}$ a value of $0.28 \mathrm{ohm}-\mathrm{m}$ at an average temperature of $6^{\circ} \mathrm{C}$ is an adequate approximation.

Deep-sea basalt core samples for which the porosity is largely vesicular and thus poorly connected give values of $a \cong 1$ and $m=2$ or slightly greater (Hyndman et al., this volume; Hamano, 1980; Christensen et al., 1979). There is, however, considerable uncertainty in these values because of the difficulties involved in sample porosity measurement and the difficulty of resaturating the samples if they were ever allowed to dry before the resistivity measurements were made. These values are consistent with the theory, discussed by Brace et al. (1965), for poorly connected porosity, in contrast to the values of $a=1$ and $m=1$ for well-connected porosity. Materials with surface conduction effects and clays may exhibit different values of $a$. Logging data for the ocean crust have so far not been of sufficient quality to define the relationship well, but values of $m$ somewhat lower than 2 are suggested (e.g., Kirkpatrick, 1979a,b; Salisbury, Donnelly, and Francheteau, 1980) for fairly well connected fracture and rubble porosity and values slightly higher than 2 (2.2) are suggested for sealed formations (Mathews et al., this volume). Becker et al. (1982) discuss the values of the constants appropriate for the upper ocean crust and choose $a=1$ and $m=2$. We take these as average values but also note the effect of lower values of $m$. Lower values will give lower computed porosities from the resistivity log, and the computed porosity will vary more slowly with resistivity. A minimum value of $m=1$ gives a porosity lower by a factor of 10 , but a factor of about 2 for $m=1.5$ is a reasonable limit. The computed porosity-depth profile from the resistivity $\log$ is shown in Figure 2. As already discussed, the reduction in the porosity interconnection caused by alteration near the bottom of the hole may give porosity values that are too low.

From the combination of sample and log data, the upper $400 \mathrm{~m}$ of the crust at Hole $395 \mathrm{~A}$ is estimated to have an average of $8.7 \%$ total porosity, of which about half is vesicular and intergranular porosity and half is fracture and rubble porosity. The contribution to permeability and thus to hydrothermal circulation will be mainly from the 4 to $5 \%$ rubble and fracture porosity. In the bottom $100 \mathrm{~m}$ of the hole, the estimated total porosity decreases to $4.7 \%$, which the sample data suggest is largely vesicular and grain-boundary porosity. This conclusion is consistent with the downhole packer data indicating very low permeability.

\section{Formation Density}

The matrix or grain density of fresh ocean crustal basalts varies little. Significant grain density differences in the upper crust occur only in the small sections of ultramafic rocks and in weathered or strongly altered basalts. 


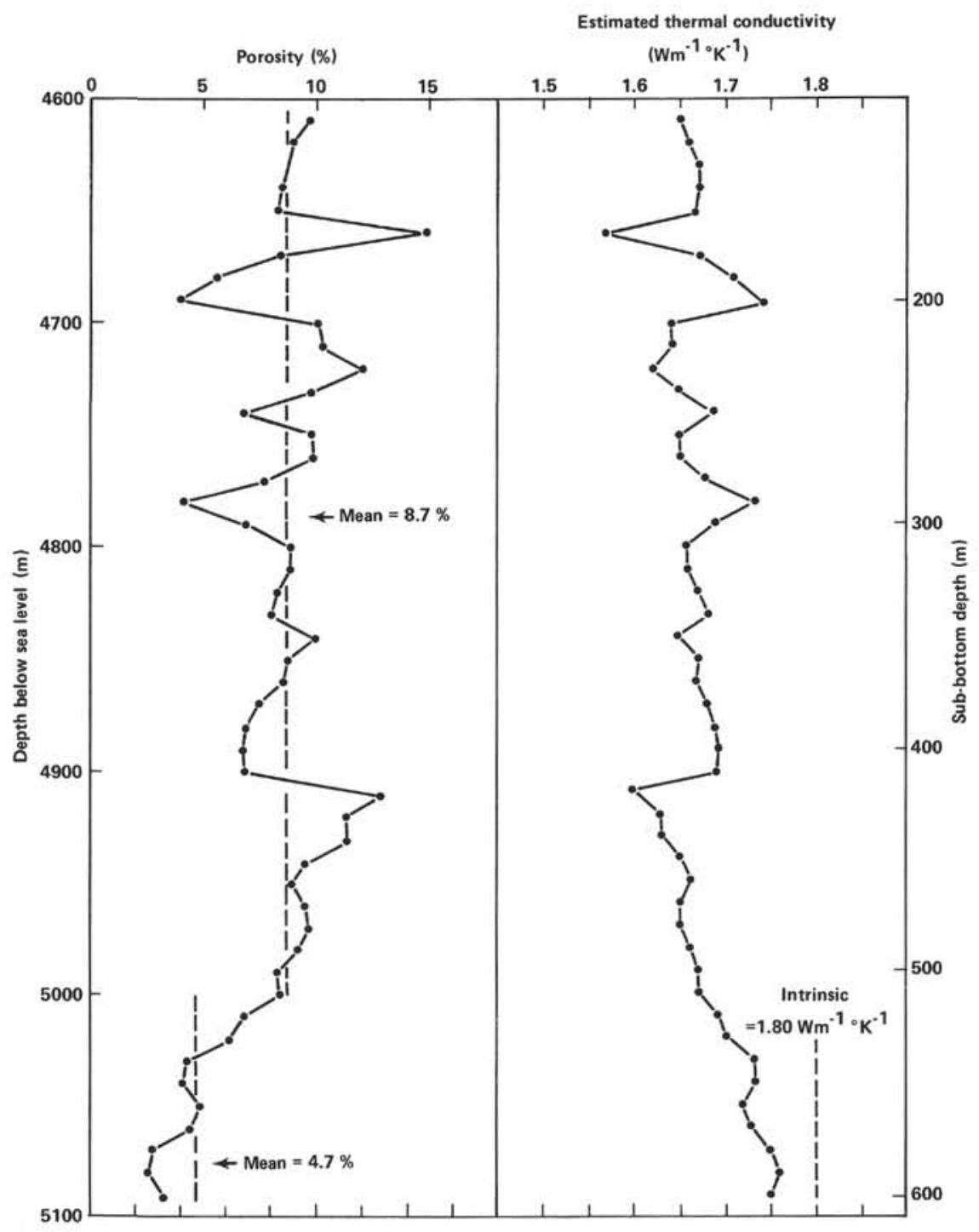

Figure 2. Formation porosity and thermal conductivity computed from resistivity log vs. depth.

Thus, the formation density in the upper crust closely follows porosity. The downhole formation density log for Hole 395A was of rather poor quality. The main zones of low-density, high-porosity rubble and fractured rocks are well delineated, but the actual density values may be significantly in error (Mathews et al., this volume). The main problem is probably poor contact of the sonde with the hole wall, so the densities will tend to be too low. Even in the massive sections with smooth borehole walls, there may be a systematic error because of the lack of accurate tool calibration for oceanic basalts. The maximum log density in the hole is about 2.8 to $2.82 \mathrm{~g} \mathrm{~cm}^{-3}$, whereas the sample data give a mean density of $2.86 \mathrm{~g} \mathrm{~cm}^{-3}$ over this interval (Unit $\mathrm{P}_{2}$ ) and an overall mean of $2.84 \mathrm{~g} \mathrm{~cm}^{-3}$. This suggests that the log density calibration may be too low.

The best estimate of the density of the formation penetrated by the hole comes from the porosity, which in turn is estimated from the resistivity log. The bulk density is given by the relation $\rho=\rho_{g}-\phi\left(\rho_{f}\right)$. The grain density $\rho_{g}$ is estimated from sample measurements to be
$2.95 \mathrm{~g} \mathrm{~cm}^{-3}$, and the fluid density $\rho_{f}$ is assumed to be that of seawater $\left(1.02 \mathrm{~g} \mathrm{~cm}^{-3}\right)$, giving $\rho=2.95-1.93 \phi$ $\mathrm{g} \mathrm{cm}^{-3}$. This relation should give in situ density for the formation penetrated by Hole $395 \mathrm{~A}$ to better than \pm 0.04 $\mathrm{g} \mathrm{cm}^{-3}$, except for the short plutonic section. Conversely, density should give porosity to better than $\pm 3 \%$ porosity. The computed density is shown in Figure 3, along with the density log. The agreement is only fair, as expected from the poor quality of the log. If the log were of higher quality, the differences would be good indicators of variations in matrix density, that is, of nonbasaltic sections or alteration, or of variations in pore structure that affect the resistivity-porosity relation. The mean computed density for the upper $400-\mathrm{m}$ section is $2.78 \mathrm{~g} \mathrm{~cm}^{-3}$; an average value of about $2.86 \mathrm{~g} \mathrm{~cm}^{-3}$ characterizes the bottom $100 \mathrm{~m}$ of the hole.

\section{Formation Velocity}

Estimates of upper crustal velocities came from sample data, downhole logging, the oblique seismic experiment employing the DARPA borehole seismometer, and 


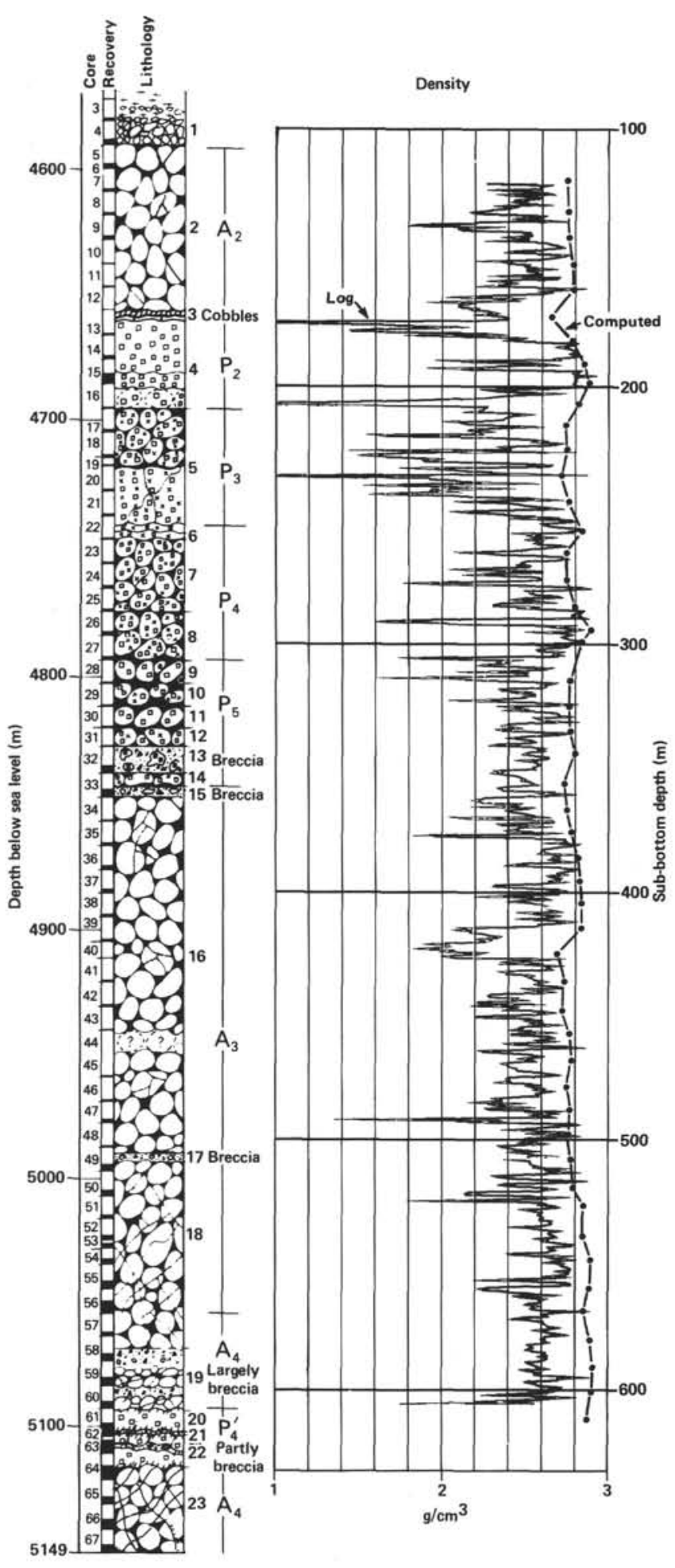

Figure 3. Density log and formation density computed from resistivity log vs. depth. Lithology from Melson, Rabinowitz, et al. (1979b).

an OBS and sonobuoy seismic refraction study. The mean compressional-wave sample velocity at simulated in situ conditions is $6.00 \mathrm{~km} \mathrm{~s}^{-1}$ at an average estimated porosity of $5 \%$. The mean shear-wave velocity is $3.18 \mathrm{~km} \mathrm{~s}^{-1}$ and the Poisson's ratio is 0.30 . The downhole log appeared to give valid data only for the bottom $100 \mathrm{~m}$ of the hole, where the log reached 5.4 to $5.5 \mathrm{~km} \mathrm{~s}^{-1}$ : Since this is a very massive section where a velocity of over $5.5 \mathrm{~km} \mathrm{~s}^{-1}$ is expected, even here the log velocities may be too low. A better estimate is available through the porosity computed from the resistivity log.

Relations between velocity and porosity for the upper ocean crust have been presented by Hyndman et al. (this volume), mainly on the basis of sample data (e.g., Christensen and Salisbury, 1975) and limited log data (Kirkpatrick, 1979a,b). In polynomial form, the relations are as follows:

$$
\begin{aligned}
& V_{p}=6.44-9.61 \phi+7.20 \phi^{2} \\
& V_{s}=3.42-6.54 \phi+7.01 \phi^{2} \\
& \sigma=0.24+0.5 \phi
\end{aligned}
$$

The velocity estimates should be accurate to within $0.2 \mathrm{~km} \mathrm{~s}^{-1}$, but the estimate of Poisson's ratio, $\sigma$, is highly uncertain. The computed compressional-wave formation velocities are shown in Figure 4. The mean computed velocities for the upper $400 \mathrm{~m}$ of the crust are $\bar{V}_{p}=5.66, \bar{V}_{s}=2.90$, and Poisson's ratio $\sigma=0.28$, reflecting a mean estimated porosity of $8.7 \%$, which decreases to about $4.7 \%$ below $400 \mathrm{~m}$, giving velocities and a Poisson's ratio of about $V_{p}=6.00, V_{s}=3.15$, and $\sigma=0.26$, respectively. These velocity values are fairly close to the sample results from this section of 6.4 and $3.4 \mathrm{~km} \mathrm{~s}^{-1}$, although the Poisson's ratio of the samples $(0.31)$ is much higher. Low values of Poisson's ratio are consistent with some field data for the upper crust (Spudich and Orcutt, 1980).

The borehole seismometer acquired quite accurate upper crustal velocity data for the region surrounding the borehole. An important result of this study (Jacobson et al., this volume) was the detection of an upper crustal layer approximately $0.6 \mathrm{~km}$ thick with an average velocity of at least $4.5 \mathrm{~km} \mathrm{~s}^{-1}$, overlying material with a velocity of at least $4.6 \mathrm{~km} \mathrm{~s}^{-1}$. The transition probably corresponds to the velocity increase defined in the formation near the bottom of the hole.

The seismic refraction survey carried out before drilling (Hussong et al., 1979) indicated a very irregular velocity structure with 0.5 to $1.2 \mathrm{~km}$ of approximately $4.6 \mathrm{~km} \mathrm{~s}^{-1}$ material overlying approximately $6.6 \mathrm{~km} \mathrm{~s}^{-1}$ material. The upper crustal velocities at the site were higher than for most of the surrounding area.

The velocity of the upper layer, determined by refraction, is considerably lower than that estimated from porosity, suggesting either that the porosity estimates are too low or that the velocity-porosity relation used is not applicable. For example, the simple time-average relation (e.g., Kirkpatrick, 1979a, b) gives closer agreement $\left(4.85 \mathrm{~km} \mathrm{~s}^{-1}\right)$. Alternatively, the refraction path sampled in Layer 2 by the DARPA experiment is much longer than that sampled by drilling ( $3 \mathrm{~km}$ vs. $500 \mathrm{~m})$, and may have a quite different velocity or a pronounced horizontal to vertical velocity anisotropy. That the velocity in the upper layer is actually higher is confirmed by an interval velocity of $5.0 \mathrm{~km} \mathrm{~s}^{-1}$ determined from a verti- 


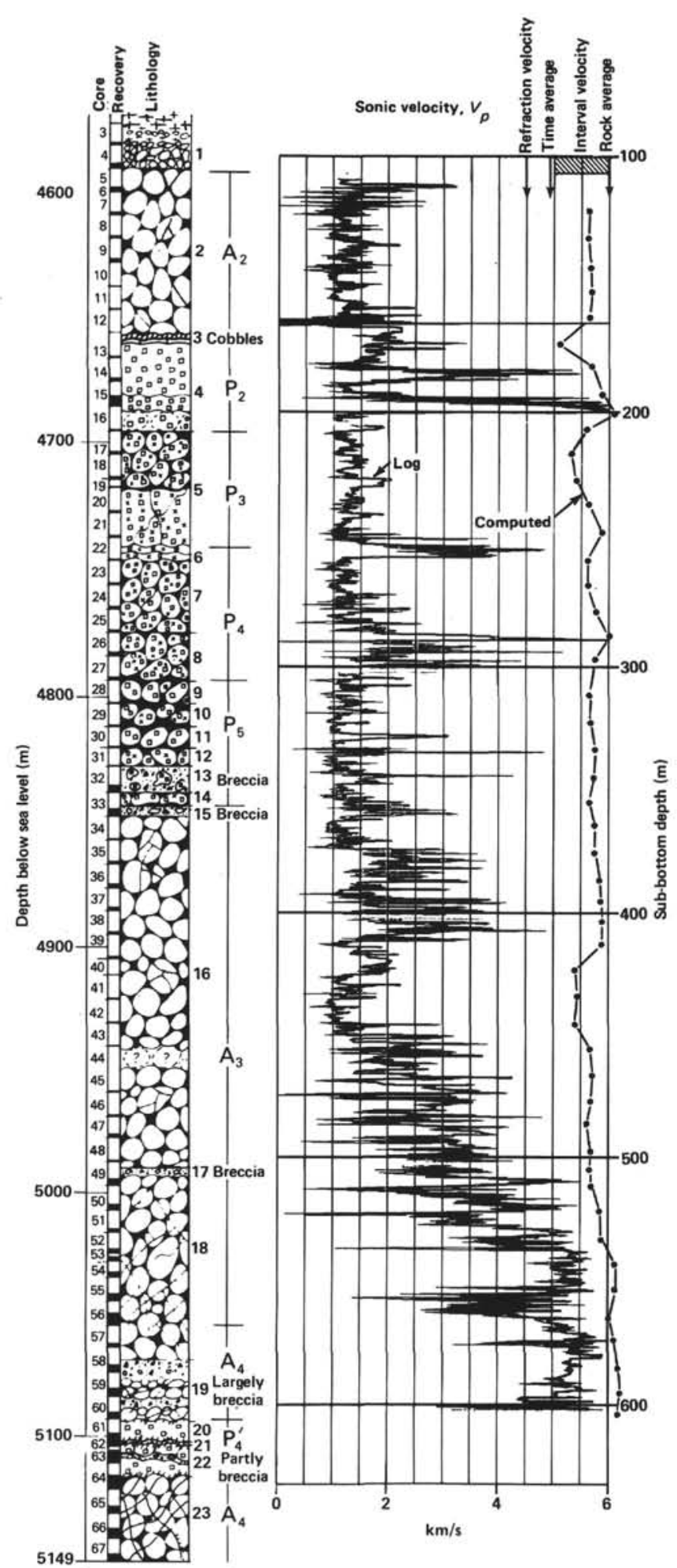

Figure 4. Compressional-wave velocity log and compressional-wave formation velocity computed from resistivity log vs. depth. Lithology from Melson, Rabinowitz, et al. (1979b). Refraction velocity from Jacobsen et al. (this volume).

cal-incidence shot during the refraction experiment for the interval from the mudline to the DARPA tool at $609 \mathrm{~m}$ sub-bottom. Although the interpretation is complicated by the presence of buried basement scarps adja- cent to the borehole, the velocity of the upper basement layer is clearly in excess of $5.00 \mathrm{~km} \mathrm{~s}^{-1}$, since the measured interval velocity includes a layer of low-velocity sediments. The average sample velocity of $6.00 \mathrm{~km} \mathrm{~s}^{-1}$, however, places a clear upper bound on the interval velocity (Fig. 4). If the average formation velocity is between 5.00 and $6.00 \mathrm{~km} \mathrm{~s}^{-1}$, then the average porosity of the section is between 17 and $5 \%$ and the value of $m$ in Archies Law is between 2.8 and 1.7.

\section{Thermal Properties}

The formation thermal properties have been estimated from sample measurements and from the computed downhole porosity. The mean sample thermal conductivity is $1.77 \mathrm{~W} \mathrm{~m}^{-10} \mathrm{~K}^{-1}$, the mean thermal diffusivity is 0.68 $\mathrm{mm}^{2} \mathrm{~s}^{-1}$, and the mean heat capacity is $0.91 \mathrm{~J} \mathrm{~g}^{-1 \circ} \mathrm{K}^{-1}$, at an average porosity of $4.0 \%$ (Hyndman et al., this volume). A number of models have been proposed relating thermal conductivity to porosity $\phi$, but the most appropriate appears to be that of Robertson and Peck (1974), in which

$$
\kappa=(1.36-0.60 \phi)^{2} \mathrm{~W} \mathrm{~m}^{-1}{ }^{\circ} \mathrm{K}^{-1}
$$

for the average olivine content of about $7 \%$ appropriate for Hole 395A. The porosity-diffusivity relation (Hyndman et al., this volume) is

$$
\kappa=(1.36-0.60 \phi)^{2} /(2.55+1.63 \phi) \mathrm{mm}^{2} \mathrm{~s}^{-1}
$$

These relations should provide upper crustal conductivity and diffusivity estimates to within $\pm 0.07 \mathrm{~W} \mathrm{~m}^{-1}$ ${ }^{\circ} \mathrm{K}^{-1}$ and $\pm 0.05 \mathrm{~mm}^{2} \mathrm{~s}^{-1}$, respectively. The profiles for the formation penetrated by the hole are shown in Figure 2. The thermal conductivity average estimated for the upper $400 \mathrm{~m}$ of the basement is $1.71 \mathrm{~W} \mathrm{~m}^{-1}$ ${ }^{\circ} \mathrm{K}^{-1}$. The bottom $100 \mathrm{~m}$ of the hole averages $1.77 \mathrm{~W}$ $\mathrm{m}^{-10} \mathrm{~K}^{-1}$.

\section{Formation Permeability}

One successful measurement of permeability obtained by the downhole packer gave a value of 3 to $9 \mu$ darcies near the base of the hole, but the permeability in the upper part of the hole must be much greater (Langseth et al., this volume). Measurements of permeability over an $800-\mathrm{m}$ interval in the bottom of Hole 504B, half of which displayed an average bulk porosity of 8 to $9 \%$ and half of which averaged $2 \%$ (Fig. 5), gave an average permeability of about $200 \mu$ darcies (Anderson, Newmark, and Zoback, 1982). Since permeability varies inversely with the length of the test interval and the permeability in the lower half was negligible (1-10 $\mu$ darcies by analogy with our measurements in a zone of similar porosity), we estimate the permeability in both the upper half of the 800 -m test interval in Hole 504B and the upper $400 \mathrm{~m}$ of the crust in Hole 395A to be about $400 \mu$ darcies, since they have similar porosities.

\section{Magnetic Properties}

Estimates of the intensity of magnetization and the magnetic susceptibility of the crustal section were made 


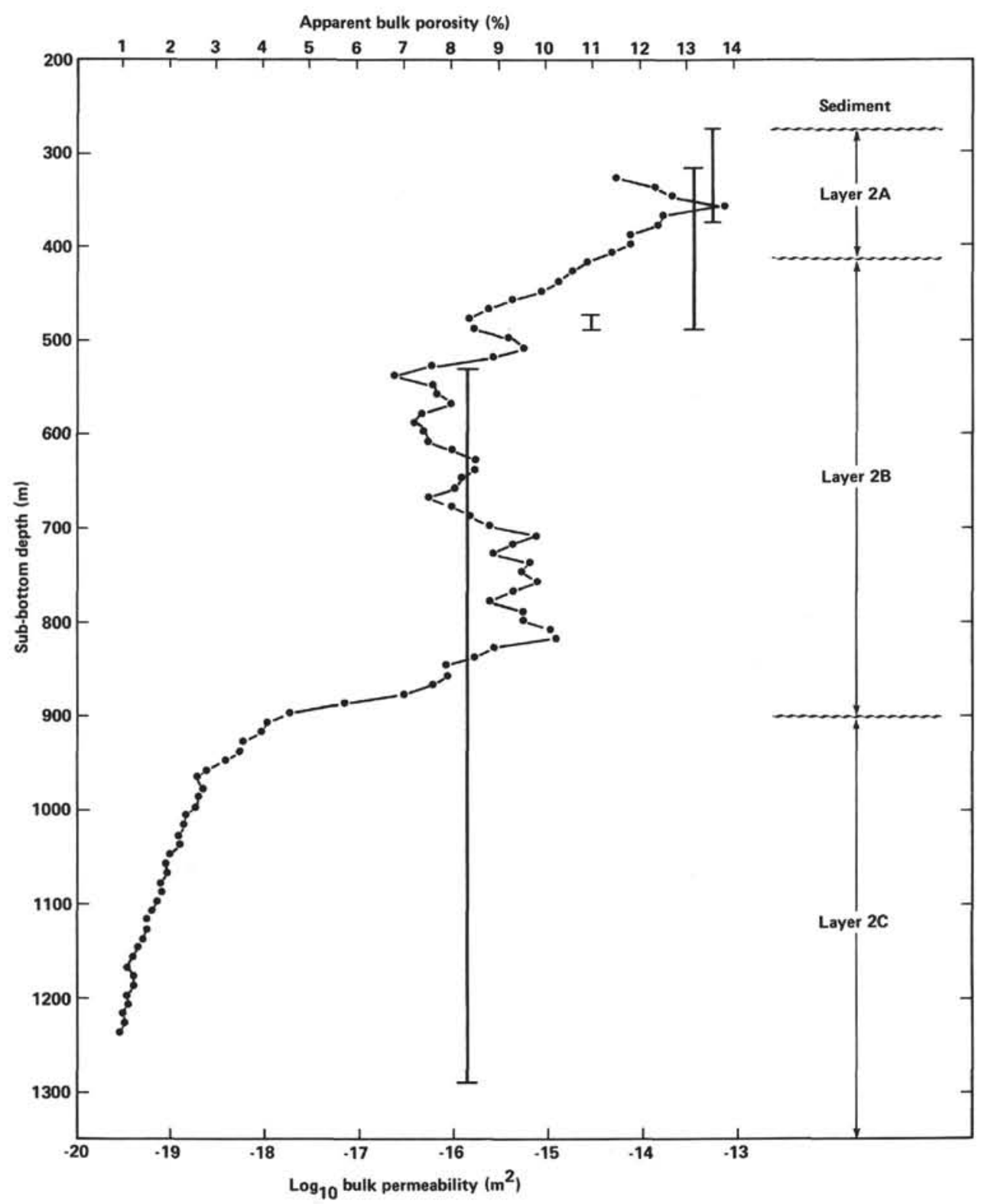

Figure 5. Bulk porosity and permeability vs. depth in Hole 504B on the Costa Rica Rift. Porosities are calculated from resistivity log using Archie's Law (1942) with $a=1$ and $m=2$. The permeabilities were measured in situ by Anderson and Zoback (1982) and Anderson, Newmark, and Zoback (1982). Figure from Becker et al. (1982).

from core analysis and logging and surface data. The core measurements for Hole 395A (Johnson, 1979) show an average magnetization, $J_{\mathrm{NRM}}$, of $3.78 \times 10^{-3} \mathrm{emu} /$ $\mathrm{cm}^{3}$, which tends to decrease with depth, and an average susceptibility of $2.6 \times 10^{-2}$ SI units, assuming no recovery bias. The logs, on the other hand, suggest an average susceptibility of $1.4 \times 10^{-2}$ SI units in the upper $400 \mathrm{~m}$ and a slightly lower value, $1.2 \times 10^{-2}$ SI units, in the lower $100 \mathrm{~m}$ (Ponomarev and Nechoroshkov, this volume). Unfortunately, the downhole magnetometer only measured the vertical component of the field, so no direct comparison can be made between laboratory and logging magnetization data. Like the laboratory magnetization data, the vertical anomalous component of the magnetic field measured by logging tends to decrease with depth.

\section{CONCLUSIONS}

A considerable improvement in our understanding of upper crustal lithology, bulk physical properties, and formation properties has been obtained by combining downhole logs and measurements with laboratory sample measurements and larger-scale geophysical data. In addition to confirming the lithologic units identified in the core on'Leg 45, including two plutonic units, a systematic increase in bulk porosity from the bottom to the top of each major basalt unit was observed. Each major unit is thus interpreted to represent an eruptive cycle 
from a different magma chamber, from which successive flows erupted at steadily decreasing temperatures and thus increasing viscosities.

A pronounced change in physical properties is evident in the bottom $100 \mathrm{~m}$ of the hole, notably a rapid increase in electrical resistivity. Since this depth coincides with a rapid increase in temperature and rock alteration, and a decrease in permeability to nearly intrinsic values, it probably represents the maximum depth of hydrothermal circulation. The quality of many of the downhole logs was poor, but useful estimates of bulk physical properties have been obtained from the good logs, particularly the resistivity log, since porosity can be determined from resistivity and most of the formation properties are closely related to porosity. The porosity average for the upper $400 \mathrm{~m}$ of the crust penetrated by the hole is about $9 \%$, of which half is fairly uniformly distributed vesicular and grain-boundary porosity and half is larger-scale fracture and rubble porosity. The large-scale porosity is concentrated in a few very high porosity (up to $20 \%$ ) zones that are inferred to have very high permeability. Since the porosity decreases by a factor of 2 and the formation velocity increases to $6.00 \mathrm{~km}$ $\mathrm{s}^{-1}$ in the lower $100 \mathrm{~m}$ of the section, we conclude on the basis of physical properties that Hole 395A penetrated the Layer $2 \mathrm{~B} / 2 \mathrm{C}$ transition. On the basis of petrology, we conclude that this boundary represents the point at which infilling by alteration products causes the formation velocity to approach the intrinsic velocity of basalt.

\section{ACKNOWLEDGMENTS}

We are indebted to Captain Clarke and the crew and staff of the Glomar Challenger for their assistance during Leg 78B. Many of the instrument deployments conducted on this leg had never been done before and were technologically challenging. Without their professionalism, ingenuity, and perseverance, we could never have achieved our goals. This chapter is Earth Physics Branch Contribution 1090.

\section{REFERENCES}

Anderson, R. N., Honnorez, J., Becker, K., Adamson, A. C., Alt, J. C., Emmermann, R., Kempton, P. D., Kinoshita, H., Laverne, C., Mottl, M. J., and Newmark, R. L., 1982. DSDP Hole 504B, the first reference section over $1 \mathrm{~km}$ through Layer 2 of the oceanic crust. Nature, 300:589-594.

Anderson, R. N., Newmark, R. L., and Zoback, M. D., 1982. In situ permeability variation in the upper kilometer of the oceanic crust of the Costa Rica Rift. Eos Trans. A.G.U., 63:434.

Anderson, R. N., and Zoback, M. D., 1982. Permeability, underpressure, and convection in the oceanic crust near the Costa Rica Rift, eastern equatorial Pacific. J. Geophys. Res., 87:2860-2868.

Archie, G. E., 1942. The Electrical Resistivity Log as an Aid in Determining some Reservoir Characteristics. J. Petrol. Technol., 5:1-8.

Aumento, F., Melson, W. G., et al., 1977. Init. Repts. DSDP, 37: Washington (U.S. Govt. Printing Office).

Becker, K., Langseth, M., Von Herzen, R. P., and Anderson, R. N., 1983. Deep crustal geothermal measurements, Hole 504B, Costa Rica Rift. J. Geophys. Res., 88:3447-3457.

Becker, K., Von Herzen, R. P., Francis, T. J. G., Anderson, R. N. Honnorez, J., Adamson, A. C., Alt, J. C., Emmermann, R., Kempton, P. D., Kinoshita, H., Laverne, C., Mottl, M. J., and Newmark, R. L., 1982. In situ electrical resistivity and bulk porosity of the oceanic crust Costa Rica Rift. Nature, 300:594-598.

Bougault, H., Treuil, M., and Joron, J., 1979. Trace elements in basalts from $23^{\circ} \mathrm{N}$ and $36^{\circ} \mathrm{N}$ in the Atlantic Ocean: Fractional crystallization, partial melting, and heterogeneity of the upper mantle.
In Melson, W. G., Rabinowitz, P. D., et al., Init. Repts. DSDP, 45: Washington (U.S. Govt. Printing Office), 493-506.

Brace, W. F., Orange, A. S., and Madden, T. R., 1965. The effect of pressure on the electrical resistivity of water-saturated crystalline rocks. J. Geophys. Res., 70:5669-5678.

Christensen, N. I., Hyndman, R. D., Hull, J. M., and Salisbury, M. H., 1979. Seismic velocities, electrical resistivities, densities and porosities of basalts from DSDP Leg 46. In Dmitriev, L., Heirtzler, J., et al., Init. Repts. DSDP, 46: Washington (U.S. Govt. Printing Office), 383-388.

Christensen, N. I., and Salisbury, M. H., 1975. Structure and constitution of the lower oceanic cryst. Rev. Geophys. and Space Phys., 13:57-86.

Curray, J. R., Moore, D. G., et al., 1982. Init. Repts. DSDP, 64: Washington (U.S. Govt. Printing Office).

Davis, E. E., 1982. Evidence for extensive basalt flows on the seafloor. Geol. Soc. Am. Bull., 93:1023-1029.

Drury, M. H., and Hyndman, R. D., 1979. The electrical resistivity of oceanic basalts. J. Geophys. Res., 84:4537-4545.

Hamano, Y., 1980. Physical properties of basalts from Holes 417D and 418D, In Donnelly, T., Francheteau, J., Bryan, W., Robinson, P., Flower, M., Salisbury, M., et al., Init. Repts. DSDP, 51, 52, 53, Pt. 2: Washington (U.S. Govt. Printing Office), 1457-1466.

Hussong, D. M., Fryer, P. B., Tuthill, J. D., and Wipperman, L. K., 1979. The geological and geophysical setting near DSDP Site 395, North Atlantic Ocean. In Melson, W. G., Rabinowitz, P. D., et al., Init. Repts. DSDP, 45: Washington (U.S. Govt. Printing Office), 23-37.

Johnson, D. M., 1980. Fluid permeability of oceanic basalts. In Donnelly, T., Francheteau, J., Bryan, W., Robinson, P., Flower, M., Salisbury, M., et al., Init. Repts. DSDP, 51, 52, 53, Pt. 2: Washington (U.S. Govt. Printing Office), 1473-1478.

Johnson, H. P., 1979. Paleomagnetism of igneous rock samples-DSDP Leg 45, In Melson, W. G., Rabinowitz, P. D., et al., 1979. Init. Repts. DSDP, 45: Washington (U.S. Govt. Printing Office), 387-396.

Kirkpatrick, R. J. 1979a. Results of downhole geophysical logging, Hole 396B, DSDP Leg 46. In Dmitriev, L., Heirtzler, J., et al., Init. Repts. DSDP, 46: Washington (U.S. Govt. Printing Office), 401-408.

1979b. The physical state of the oceanic crust: Results from downhole logging in the Mid-Atlantic Ridge at $23^{\circ} \mathrm{N}$. J. Geophys. Res., 84:178-188.

Melson, W. G., Rabinowitz, P. D., et al., 1979a. Init. Repts. DSDP, 45: Washington (U.S. Govt. Printing Office).

, 1979b. Site 395: $23^{\circ} \mathrm{N}$, Mid-Atlantic Ridge. In Melson, W. G., Rabinowitz, P. D., et al., Init. Repts. DSDP, 45: Washington (U.S. Govt. Printing Office), 131-264.

Robertson, E. C., and Peck, K. L., 1974. Thermal conductivity of vesicular basalt from Hawaii. J. Geophys. Res., 79:4875-4888.

Salisbury, M. H., Donnelly, T. W., and Francheteau, J., 1980. Geophysical logging in Deep Sea Drilling Project Hole 417D. In Donnelly, T., Francheteau, J., Bryan, W., Robinson, P., Flower, M., Salisbury, M., et al., Init. Repts. DSDP, 51, 52, 53, Pt. 1: Washington (U.S. Govt. Printing Office), 705-713.

Salisbury, M. H., Stephen, R., Christensen, N. I., Francheteau, J., Hamano, Y., Hobart, M., and Johnson, D., 1980. The physical state of the upper levels of Cretaceous oceanic crust from the results of logging, laboratory studies and the oblique seismic experiment at Deep Sea Drilling Project Sites 417 and 418. In Donnelly, T., Francheteau, J., Bryan, W., Robinson, P., Flower, M., Salisbury, M., et al., Init. Repts. DSDP, 51, 52, 53, Pt. 2: Washington (U.S. Govt. Printing Office), 1579-1597.

Schreiber, E., and Rabinowitz, P. D., 1979. Acoustic wave velocity measurements of oceanic crustal samples-DSDP Leg 45. In Melson, W. G., Rabinowitz, P. D., et al., Init. Repts. DSDP, 45: Washington (U.S. Govt. Printing Office), 383-386.

Spudich, P., and Orcutt, J., 1980. Petrology and porosity of an oceanic crustal site: Results from waveform modelling of seismic refraction data. J. Geophys. Res., 85:1409-1433.

Date of Initial Receipt: September 29, 1983

Date of Acceptance: October 19, 1983 